\title{
How Brand Equity Changes Service Marketing: The Case of Indonesian Service Industry
}

\begin{abstract}
Submitted 11/03/20, $1^{\text {st }}$ revision 16/05/20, $2^{\text {nd }}$ revision 24/06/20, accepted 15/08/20
Bernard T. Widjaja ${ }^{1 *}$

Abstract:

Purpose: The purpose of this research is to explain the gap between the change of service marketing and service industries in Indonesia, then to find a solution by adding the brand equity variable so that the service industry can increase.

Design/Methodology/Approach: This study uses a quantitative approach so that it can explain how much influence the change of service marketing variable has on the service industry in Indonesia, by using a mediating variable, namely brand equity, which is a problem-solving solution in improving services in the industry. Samples were taken from 300 people from various industries in Jakarta. Data analysis techniques used SEM / PLS.

Findings: The change of service marketing is not related to the service industry in Jakarta, while the change of service marketing is related to brand equity and in the end, brand equity can improve service industry. Thus, brand equity is a very important variable and becomes a problem-solving solution for the development of industrial services in Jakarta.

Practical Implications: The expected final objective of this study is to define business sustainability using the correct marketing with long term orientation. The study can be used in service marketing where brand equity can positively influence the service industry for business sustainability.

Originality/Value: The research resulted in important findings that can be applied for both as theory development and practical matter which can broadly impact the change of service marketing.
\end{abstract}

Keywords: Service-marketing, life-style marketing, brand equity, customer equity.

JEL Code: M30, M31.

Paper Type: Research study.

${ }^{1}$ Professor, Lecturer of School of Management Labora Jakarta, Indonesia, email: bernardwidjaja8989@yahoo.com 


\section{Introduction}

The progressing Indonesian economy affects people's lifestyle. One important industry that shows significant lifestyle-related development is the service industry. According to data from professional associations, there are more than 100,000 industry services with 10-15\% annual growth with USD 1.3 million business value (Antara, 2015; Ozal, 2012). Previous preliminary research classified the service industry since 1970 into four eras: The Pioneer era, the Fashion era, the Lifestyle era and the Modern Lifestyle era. The development of each era was marked by a change of market leadership, and was not able to survive as the market leader through multiple eras. Despite the potential of this industry, many consumers are unaware of the importance of the halal brand, with a relatively low response rate to halal products, halal awareness is influenced by several factors such as halal knowledge supported by halal exhibition, training and halal certification process that will affect market promotion products (Anggadwita, 2019; Utami and Asriani, 2019; Fauzi, Basrowi and Utami, 2020).

The result of preliminary exploratory research (focus group discussion and in-depth interviews) show that inferior sustainability is the problem that kept on repeated, so that industry cannot longer provide customers' demand that in turn creates customer value gap. The previous researchers also found that the needs' service customers cannot be fulfilled the marketing mix as currently defined. This leads to a strong indication that there is a new demand aspect related to a new paradigm. Furthermore, it was also found that there are emotional benefit needs that can be lifestyle indicators. The indications of a new demand aspect are also reinforced by lifestyle research conducted (Jimad et al., 2020) in the fashion field (Carraher, Parnell and Spillan, 2010), exploratory research (Musaddad and Inuwa, 2020) in consumer markets, and in study results on the relationships of brand and lifestyle conducted by Cătălin and Andreea, (2014), Islamiyati et al. (2019), and Basrowi and Utami, (2020). This body of research shows that lifestyle is a new paradigm that serves as a strong booster for shifting customer requirements.

The objective of this study is to develop a model to address the current gaps and it is expected to be an alternative theory development specified on service marketing strategies that can be applied in the market and suitable for the updated market conditions.

In the literature there have been many articles linking the change of service marketing with the service industry, but the results are quite mixed. There are those which claim that the change of service marketing has an effect on the service industry and there are those which claim that the change of service marketing has no effect on the service industry. This research is a solution study in overcoming this gap. One of them is to create a brand equity variable in mediating the relationship between the change of service marketing and the service industry in Indonesia. Therefore, researchers are trying to re-examine related issues to this matter. 


\subsection{Change of Service Marketing}

In the past, marketers were more likely to communicate in one direction. Marketers are the transmitters of information and consumers the recipients of this information. This condition is no longer valid today, because entrepreneurs or marketers must balance to talk by listening about what consumers want in order to get feedback as material for future improvements. Because the consumer is the king (Carraher, Parnell and Spillan, 2010) such changes are required. The mentality of an entrepreneur must be really ready to face all the changes that are happening at this time. Entrepreneurs who are already successful will always try to see opportunities even though they are narrow. And to be sure, there are no words to stop innovating (Cătălin and Andreea, 2014).

Every company has goals according to the expected targets. However, to achieve a company goal, of course the role of invention and innovation is needed. Invention and innovation are closely related to corporate strategy and corporate goals. Invention activities are included in the activities of technological discovery, both attached to production equipment and human resources (Teguh, 2010).

On the other hand, innovation is a step towards manifesting something that has been discovered and developed. So without innovation, we may not be able to enjoy quality products that are available in sufficient and varied quantities. From determining the goals of the company, we can see 2 aspects of invention and innovation that are interrelated with each other to create a condition in which a product in a company has a unique and differentiated value that is competitive with similar products and is able to create a market share in a targeted market.

Whether the product is good or not, of course, it is necessary to hold a product feasibility test as well as a basic survey to the customer before being deployed to the market. For example, New Cellular Products, of course, have to look at the competitive side (competitiveness) both in terms of tariffs, features, pulses or technology services. The inventions and innovations that have been carried out will be immediately identifiable both in terms of technology, from the side of tariff savings and the current developments, whether they can follow market tastes.

Invention and innovation performance will not be carried out well, if at the time of the product mix in the market, the product is not known, there is no communication to the public, information through advertising does not exist, so, it is difficult to sell the product. This problem actually occurs in companies and fundamentally, this is a problem that will make it difficult to achieve the desired company's goals.

\subsection{Brand Equity}

Brand equity is the long-term result of a good marketing mix performance. The two components have a linear relationship, the higher the marketing mix performance, 
the higher the brand equity. The brand is important in creating added value for a product or service offered to the customer. Branding has the impact of increasing the customer's loyalty, making it resistant to price changes. The brand gives financial means for revenue growth and company value (Aaker, 1991). The level of revenue of a society relates to their brand interest. Customers must be positioned to perceive the brand on the right value and to be able to appreciate the brand (Southworth and Kim, 2015).

\subsection{Service Industry}

Changes in the structure of the world economy are likely to create knowledge gaps in literature services. Some argue that the service industry reflects conventional. Critical services in areas such as medical care, transportation, financial services, and education tend to increasingly rely on technology, robots, drones, and other technologies. This change is likely to affect the way consumers perceive service quality, assess value and satisfaction attributes. It may also require new yield metrics (Lu et al., 2020).

Consumers are tired of marketing strategies in the form of advertisements that they encounter everywhere. Marketing 4.0 is present as a marketing solution that mediates between business and consumer needs. Therefore, the message you convey should not only focus on sales, but also provide solutions for what consumers need (Lovelock, 2008).

In the Marketing 4.0 book, it is explained, sellers need to identify customer frustration points (pain points), especially when using a product or service for a service. From that point of frustration, marketers must think about how the product application offered can help to solve consumer's problems (Jacoby, 2002; Hawkins and Mothersbaugh, 2010). Marketing 4.0 is a marketing approach that combines online and offline interactions that occur between sellers and consumers. Marketing 4.0 is the latest approach whose main goal is to win consumer advocacy. A combination of online and offline interactions is needed to complement each other. Technological advances have indeed enabled us to do online marketing so that it is easier and can target a wider range of customers. But online interaction is not enough (Lovelock, 2008; Morgan and Hunt, 1994; Bell et al., 2002).

In fact, offline interaction is still needed. This is necessary to touch consumers in order to get satisfying services from the products or services offered. That is why in marketing 4.0, the online market does not try to bring down the offline or traditional market. But instead they complement each other's roles (Guerin, 2006).

\subsection{Conceptual Frame}

Based on the theoretical review above, this study uses a process delivery relationship approach. When customers interact in giving and receiving a service, the interaction 
becomes the moment of truth and the service provider must maximize the interaction in order to fulfill the requirements and requests of their customer as priorities. Marketing is a profession which is the backbone of a company to spread information and company advantages. If a professional rating is taken, many applicants who are looking for work are very reluctant to register as a marketer, always associated with regular promotional targets and communications, even though marketing can be a solution to facilitate advancement in career paths. Being a successful professional marketer, you must spread value regularly to customers so that it can become a brand image and brand awareness and in the end it will increase target processing. Clear planning, tenacity and good discipline are the main requirements that can be done to create a good marketing atmosphere, while entrepreneurs who do business independently, can also think about how good marketing concepts are to bring customers to come to the business they are engaged in. Marketing is very important to do from the point of view of professionalism and entrepreneurship as a basis for increasing company goals.

In simple terms, to strengthen the brand of a product, marketing has to increase the brand name. Generally, the brand of a product will be stronger, create a brand image (branding), when the marketer carries out regular and structured promotions and evaluates what has been done. Image that is done to increase sales of a product, currently develops the term war of mouth, or chatting about the quality of a product which seeks to remind understanding of a product regarding excellence, innovation, invention and to carry out direct evidence for increased trust in a product if one person is satisfied with the concept of a company's marketing and gets a very good value, the customer will tell to friends or business partners about the value that can be taken from the product.

The existing value will be the best marketing tool. Speaking of values, (Kasali, 2006) in his book entitled Cracking Value said that the values adopted by a nation reflect what the nation believes. All of these process from what is held by the leaders, because it is the leaders who have the power to become the driving force, to become role models. However, as human subordinates have thoughts, feelings and are able to control the response of their actions, you really cannot change the traffic light that suddenly turns "red", but you can control your response by stopping or increasing the speed of the vehicle. Thus, by providing value that you are the main goal which is the rationale for a leader to drive the marketing concept that will be implemented in the field by marketers the value offered will be useful as a basic need by customers increasing brand awareness towards product or company.

The performance of the marketing mix generates overall satisfaction which affects brand equity (Delgado-Ballester and Munuera-Alemán, 2005). Additionally, customer equity is the result of long term brand equity which can only occur if the customer presents significantly high loyalty (ultimate loyalty) that is formed from the accumulation of ultimate customer value, trustworthiness, attachment and 
commitment (Lassar, Mittal and Sharma, 1995). Hence, customer equity will only result from good brand equity.

Figure 1. Research model

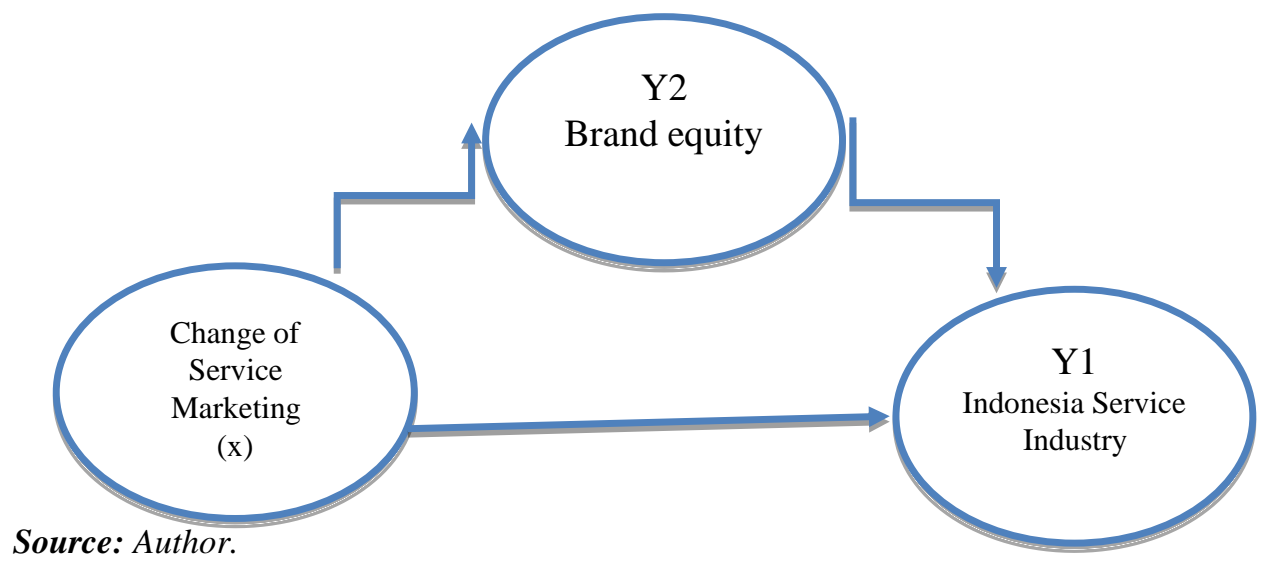

\section{Research Methods}

This study is based on data from 200 service industry customers in Jakarta, used here as the lifestyle benchmark in Indonesia. The unit of analysis is the individual, the customers of services in Jakarta. This research used one shot time horizon with cross-section data type, stratified random sampling. Previously, the researcher conducted preliminary research in two stages, exploratory research (using focus group discussion and in-depth interview techniques) and descriptive-quantitative research with factorial analysis to find dimension of lifestyle mix (Widjaja, 2016). This study continues previous research using explanatory research with structural equation modeling/ PLS to verify hypothesis.

\section{Results and Discussion}

The model test results fulfill the fit requirement as shown value is 0.021 (less than 0.5) for RMSEA score, 0.92 for GFI, and 0.90 (more than 0.90) for AGFI. With a small chi-square and 0.2192 (more than 0.5) P-value, it can be said that the model supports the theory.

Hypothesis 1 states that the change of service marketing has a significant effect on the service industry, but the results of the study state that change of service marketing has no significant effect on the service industry. Therefore, the hypothesis is rejected. Hypothesis 2 states that the change of service marketing has a significant effect on brand equity. The results showed that the change of service marketing had a significant effect on brand equity so that the hypothesis was accepted. Brand equity in hypothesis 3 states that it has a significant effect on the service industry. The results showed that brand equity has a significant effect on the service industry. 
Thus, hypothesis 3 is accepted. Since the change of service marketing cannot improve the service industry, brand equity is a very important variable (Table 1).

Figure 2. T-Test Diagram

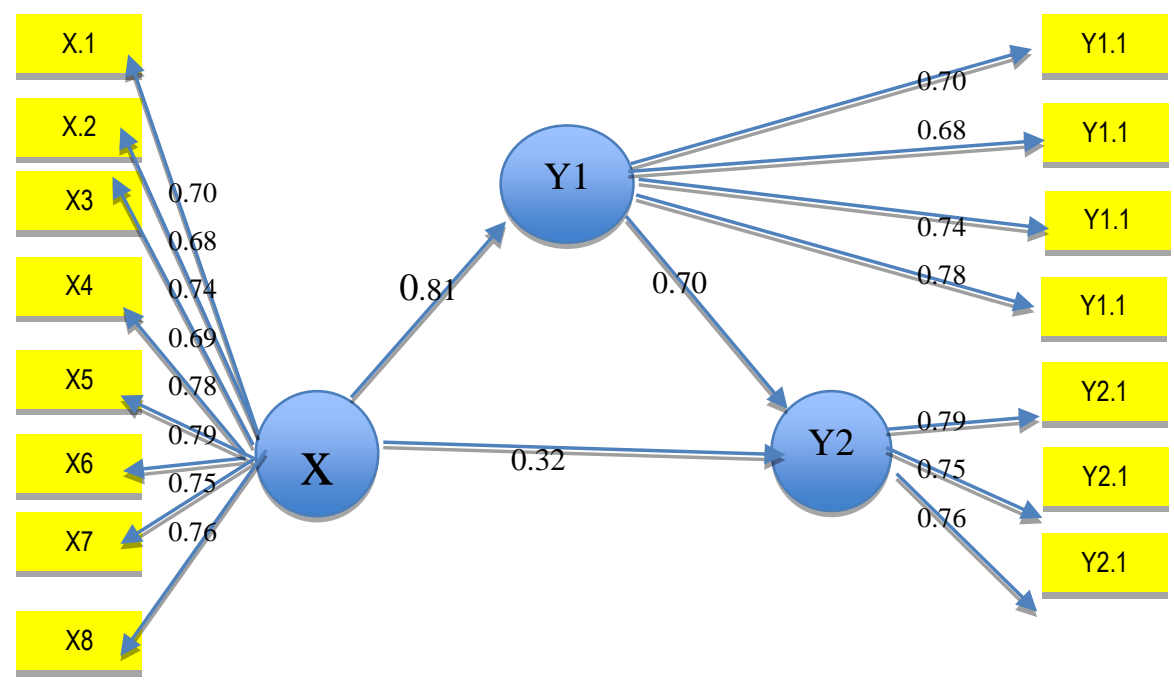

Note: $X=$ Change of Service Marketing, $Y 1=$ Brand Equity, $Y 2=$ Service Indusstry.

Source: Author.

Table 1. Estimated Parameter of inter-Variable Influence Size

\begin{tabular}{|l|l|l|}
\hline The relationship between variables & Result & Information \\
\hline Change of Service Marketing $\rightarrow$ Service Industry. & 0.32 & Non significant \\
Change of Service Marketing $\rightarrow$ Brand equity. & 0.81 & Significant \\
Brand Equity $\rightarrow$ Service Industry & 0.72 & Significant \\
\hline
\end{tabular}

Source: Author.

\section{Conclusion}

The findings in this study are that brand equity is the most important issue in improving marketing performance. Brand equity is a problem solving when the change of service marketing affects the service industry in Jakarta. Some industries in practice always prioritize change service marketing but have not succeeded in improving industrial services. The change of service marketing is not related to the service industry in Jakarta, while the change of service marketing is related to brand equity and in the end, brand equity can improve service industry. Thus, brand equity is a very important variable and becomes a problem-solving solution for the development of industrial services in Jakarta.

\section{References:}

Aaker, D.A. 1991. Managing Brand Equity. Boston, The Free Press. 
Antara. 2015. Pertumbuhan Bisnis Salon meningkat 10-15\%', beritasatu.com. Available at: https://www.beritasatu.com/ ekonomi/275419/pertumbuhan-bisnis-salon-meningkat1015.

Basrowi and Utami, P. 2020. Building Strategic Planning Models Based on Digital Technology in the Sharia Capital Market? Journal of Advanced Research in Law and Economics, 11(3), 747-754. doi: https://doi.org/10.14505/jarle.v11.3(49).06.

Bell, D. et al. 2002. Seven Barriers to Customer Equity Management. Journal of Service Research, 5(1), 77-85. doi: 10.1177/1094670502005001008.

Carraher, S., Parnell, J.A., Spillan, J.E. 2010. Customer service-orientation of small retail business owners in Austria, The Czech Republic, Hungary, Latvia, Slovakia, and Slovenia. Baltic Journal of Management, 4(3), 251-268. doi: http://dx.doi.org/10.1108/17465260910990975.

Cătălin, M.C., Andreea, P. 2014. Brands as a Mean of Consumer Self-expression and Desired Personal Lifestyle. Procedia-Social and Behavioral Sciences, 109, 103-107. doi: 10.1016/j.sbspro.2013.12.427.

Delgado-Ballester, E., Munuera-Alemán, J.L. 2005. Does brand trust matter to brand equity? Journal of Product and Brand Management, 14(3), 187-196. doi: 10.1108/10610420510601058.

Fauzi, Basrowi, Utami, P. 2020. Model e-Marketing berbasis Fintech Syariah Berdasarkan Tinjauan Lingkungan Eksternal dan Internal untuk Pengembangan Wisata Halal Di Indonesia. Jurnal Syarikah, 6(1), 58-66. Available at: https://ojs.unida.ac.id/JSEI/article/view/2157.

Grisna Anggadwita. 2019. Halal Label vs Product Quality in Halal Cosmetic Purchasing Decisions. IKONOMIKA, 4(2), 227-242.

Guerin, S. 2006. Why People Buy Things They Don't Need: Understanding and Predicting Consumer Behavior. Journal of Product Innovation Management, 23(3), 293-295. doi: 10.1111/j.1540-5885.2006.00201_1.x.

Hawkins, D.I., Mothersbaugh, D. 2010. Consumer behavior: Building marketing strategy. Boston, McGraw-Hill Irwin.

Islamiyati, I. et al. 2019. The Legal Reform of the Waqf Law Resolution Based on Pancasila. Diponegoro Law Review, 4(2), 226. doi: 10.14710/dilrev.4.2.2019.226-243.

Jacoby, J. 2002. Stimulus-organism-response reconsidered: An evolutionary step in modeling (consumer) behavior. Journal of Consumer Psychology, 12(1), 51-57. doi: $10.1207 / 153276602753338081$.

Jimad, H. et al. 2020. Leadership Strategy of State University Public Service Agency to Increasing Organizational Performance in Indonesia. International Business and Accounting Research Journal, 4(1), 23-36. doi: http://dx.doi.org/10.15294/ibarj.v4i1.110.

Kasali, R. 2006. Pop Marketing dalam Konteks Pemasaran Indonesia. Jakarta, Gramedia.

Lassar, W., Mittal, B., Sharma, A. 1995. Measuring customer-based brand equity. Journal of Consumer Marketing, 12(4), 11-19. doi: http://dx.doi.org/10.1108/07363769510095270.

Lovelock, C. 2008. Services marketing people, technology, strategy, 5/e. India, Pearson Education.

Lu, V.N. et al. 2020. Service robots, customers and service employees: what can we learn from the academic literature and where are the gaps? Journal of Service Theory and Practice, 30(3), 361-391. doi: 10.1108/JSTP-04-2019-0088.

Morgan, R.M., Hunt, S.D. 1994. The Commitment-Trust Theory of Relationship Marketing. Journal of Marketing, 58, 20-28. doi: 10.1177/002224299405800302. 
Southworth, S., Kim, M. 2015. Perceived quality of Asian brands by U.S. consumers: Case of cosmetic brand using age as a moderator. Advances in International Marketing, 26, 235-253. doi: 10.1108/S1474-797920150000026011.

Teguh, M. 2010. Ekonomi Industri. Jakarta, PT.Raja Grafindo Persada.

Utami, P., Asriani. 2019. Optimization of Utilization of E-Commerce on Halal Products in Indonesia. Eastern Journal of Economics and Finance, 4(1), 14-23. doi: 10.20448/809.4.1.14.23.

Widjaja, B.T. 2016. Life-style marketing: analternative Theoritical Model of Service Marketing Dimension. International Journal of Applied Business and Economic Research (IJABER), 14(13), 9359-9376. Available at: http://serialsjournals.com/index.php?route=product/product/volumearticle\&issue_id= $151 \&$ product_id=343. 